\title{
INDEX TO VOL. 31
}

\author{
(including CRL News issues)
}

Prepared by Richard Schimmelpfeng

\section{ABBREVIATIONS}

Standard abbreviations for names of organizations, ALA, ACRL LC, etc., are alphabetized as if spelled out. Other abbreviations:

$\begin{array}{ll}\text { appt. } & \text { - appointment } \\ \text { cat.(s) } & \text {-catalog(s) } \\ \text { coll. } & \text { - college } \\ \text { ed. } & \text { - editor, edition } \\ \text { l.(s), In.(s) } & \text { - library(ies), librarian(s) } \\ \text { port. } & \text { - portrait } \\ \text { ref. } & \text { - reference } \\ \text { rev. } & \text {-review(er) } \\ \text { s (before page numbers) } & \text {-CRL News issues } \\ \text { univ. } & \text { - university }\end{array}$

\section{A}

Abstracts, 61-64; 124-29; 207 $11 ; 286-89 ; 360-63 ; 425-27$ "Academic in deed," Moriarty, $14-17$

"Academic 1. procedures for providing students with required viding students with required Hubbard and Stursa, 103-06

"Academic status for coll. and univ. Ins.-problems and prospects," Smith, 7-13

Acquisitions, s5-10; s28-32; s7377; s97-108; s145-46; sI7885; s212; s241-44; s275; s297-300; s328

Agricultural Sciences Information Network Development Plan, EDUCOM, rev. of, 281 82

"Allocating book funds: control or planning?" Schad, 155-59

Aman, Mohammed M., "Bibliographical services in the Arab countries," 249-59

ALA, Activities Committee on New Directions, ACRL comment, s133-34

ALA, awards, nominations sought, sl-2; s324-27

ALA, Council, censure resolution on desegregation, s94-95

ALA, Executive Director, Search Committee for, s293-94

ALA, midwinter meeting, Los Angeles, Jan. 17-23, 1971. schedule of meetings, s323-24 Anderson. John F., rev., 356-57

Anderson, LeMoyne W., rev., 281-82

Anderson, Ottilia C., Index to Festschriften in Lnship, rev. of, 413-14
"The Annex L. of Princeton Univ.: the development of a compact storage 1.," Conger, 160-68

"The application of computers to 1. technical processing," Veaner, 36-42

Appointments, s17-19; s56-57; s88-89; s122-25; s165-66; s199; s229-30; s260-61; s310. I2; s287-90; s347-50

Arnold, Edmund R., rev., 35556

"Article use and its relationship to individual user satisfaction," Trueswell, 239-45

ACRL. Academic Status Committee, standards for Ins., $\$ 269$ 72

ACRL, annual conference, Detroit. 1970, tentative schedule, s173-75

ACRL, Art Ls. Subsection, report of meetings, s67-69

ACRL, Board of Directors, meeting, Chicago, Jan. 20, 23, 1970 brief of minutes, s13541 ; meeting, Detroit, June 29, July 2, 1970, brief of minutes, s317-22

ACRL, comment on ALA Activities Committee on New Directions, s133-34

ACRL, grants awarded, s26

ACRL, membership meeting, Detroit, 1970 , s237-38

ACRL, reorganization plans, s93

ACRL, Section \& Subsection Committee chairmen, s295-96

Automation, 36-42; 299-312, 318-31

"Automation stops here: a case for man-made book collections," Rouse, 147-54
B

Benge, Ronald C., Ls. and Cul tural Change, rev. of, 357-58

Berry, John, ed., Directory of L. Consultants, rev. of, 12324

"Bibliocentre: an essay in central processing at coll. level,", Ready, 50-54

"Bibliographical services in the Arab countries," Aman, 24959

"Black studies: a report for lns.," Doherty, 379-87

Blake, N. F., Caxton and His World, rev. of, 353-55

Book Pirating in Taiwan, Kaser, rev. of, 58

Books for Jr. Coll. Ls.; a Selected List of Approximately 19,700 Titles, Pirie, rev. of, $355-56$

"Books received," 59-60; 206 07; 284-86; 423-25

Braden, Irene A., The Undergraduate L., rev. of, 417-18

Bragg, William Lawrence, ed., Physical Sciences, Royal Institution L. of Science, rev. of, 422

British Univ. Ls., Neal, rev. of, 421-22

Buildings, s10-11

Bundy, Mary Lee, Reader in Research Methods for Lnship, rev. of, 419

Burke, Redmond A., "The separately housed undergraduate 1 . versus the univ. 1.," 399402

C

Cartwright, Kelley L., rev, 123 
Cassata, Mary B., "Teach-in: the academic ln.'s key to status?" 22-27

Castagna, Edwin, rev., 203-04

Cataloging U.S.A., Dunkin, rev, of, 204-05

"Catcall," Shaw, 89-95

Caxton and His World, Blake, rev. of, 353-55

Centralized Book Processing: a Feasibility Study Based on Colorado Academic Ls., Leonard, Maier and Dougherty, rev. of, 119-21

Cireulation records, ALA Executive Board statement on, s239

Clayton, Howard, "Femininity and job satisfaction amon male I. students at one mid. western univ," 388-98

"Community use of jr. coll. Is.a symposium" [results of a survey of $j r$. coll. Is. in Mar. 1968 ] Josey, 185-98

Computerized L Cats.: Their Growth, Cost, and Utility, Dolby, Forsyth and Resnikoff, rev. of, 123

Conaway, Charles M., rev., 41516

Conger, Lucinda, "The Annex L. of Princeton Univ: the development of a compact storvelopment of

Cordasco, Francesco, Eighteenth Century Bibliographies, rev. of, 358-59

Cottam, Keith M., "Student employees in academic ls.," 246 48

Council on L. Resources Fellowship awards, s209-10

\section{D}

Danton, J. Periam, Index to Festschriften in Lnship, rev. of, 413-14

Davis, Donald G. "Problems in the life of a univ, In.: Thomas James, 1600-1620," 43-49; correction, 289

De Gennaro, Richard, "Harvard Univ.'s Widener L. shelflist conversion and publication program," 318-31

Directory of L. Consultants, Berry, ed., rev. of, 123-24

Doherty, Amy S., "Black studies a report for lns." "379-87

Dolby, J. L., Computerized $L$. Cats.: Their Growth, Cost, and Utility, rev, of, 123

Dougherty, Richard M., editorials, $5 ; 81 ; 225-26$; 377; Centralized Book Processing: a Feasibility Study Based on Colorado Academic Ls., rev. of, 119-21

Downs, Robert B., "Standards for univ. Is.," 28-35

Dunkin, Paul S., Cataloging U.S.A., rev, of, 204-05

Eastlick, John T., rev., 355

Edelman, IIendrik, rev, 121-22

Editorials, $5 ; 81 ; 145 ; 225-26$; $297-98 ; 377$

Education for Lnship: Report of the Working Party, New Zealand Working Party on Education for Lnship, rev. of 416-17

EDUCOM, Agricultural Sciences Information Network Develop. ment Plan, rev. of, 281-82

Eighteenth Century Bibliogra- phies, Cordasco, rev, of, 35859

Ellsworth, Ralph E., rev., 123 24

"Essentials of 1. manpower budgeting," Fairholm, 332-40; correction, 412

Esther J. Piercy Award, call for nominees, s326

European Periodical Literature in the Social Sciences and the Humanities, Vesenyi, rev. of, 414-15

F

Fairholm, Gilbert W., "Essentials of 1 . manpower budgeting," 332-40; correction, 412

Farley, John, L. Science, rev. of, 355

"Femininity and job satisfaction among male $\mathrm{I}$, students at one midwestern univ.," Clayton, 388-98

Ford, James L. C., Magazines for Millions: the Story of Specialized Publications, rev. of, 283-84

Forsyth, V. J., Computerized L. Cats.: Their Growth, Cost, and Utility, rev, of, 123

Foyle, James, rev., 122-23

Freedom to Read Foundation Board of Trustees appts., s71

"Fringe benefits for academic ]. personnel," Wright, 18-21

"From inside the DLP," Stokes, s25-26; s69-70; s95-96; s141 s176-78; s21I; s240; s272 s327-28

G

Gittelsohn, Marc, rev., 417-18

Goldhor. Herbert, An Introduction to Scientific Research in Lnship, rev. of, 283; rev., 419

The Government and Control of Ls., Stockham, rev. of, 122-23

\section{$\mathrm{H}$}

Hacker, Lois, rev., 204-05

Harrer, Gustave A., rev., 421 22

"Harvard Univ.'s Widener L shelflist conversion and publication program," De Gennaro, 318-31

Heinritz, Fred J., "Quantitative management in ls.," 232-38

Hendricks, Donald, rev., 119-2I

Heron, David W., editorial, 297 98; rev., 357-58

Heussman, John W "Standards for univ. Is.," 28-35

Hewitt, Joe, rev., 283

Hiatt, Peter, editorial, 145

A History of Education for Lnship in Colombia, Krzys and Litton, rev, of, 419-21

Holley, Edward G., rev., 41314

Horecky, Paul L., ed., Southeastern Europe: a Guide to Basic Publications, rev, of, 418-19

Iorrocks, Norman, rev., 416-17

Huhbard, Charles L., "Academic 1. procedures for providing students with required reading materials," 103-06

Hıff, William H., rev., 283-84

$$
\text { I }
$$

Index to Festschriften in Lnship,
Danton and Anderson, rev, of, 413-14

"Information retrieval from the management point of view," Kaplan, 169-73

Information Storage and Retrieval Systems for Individual Researchers, Jahoda, rev. of, 415 16

An Introduction to Scientific Research in Lnship, Goldhor, rev, of, 283

An Introduction to Univ. L. Administration, Thompson, rev. of, $421-22$

\section{J}

Jahoda, Gerald, Academic 1. procedures for providing students with required reading materials," 103-06; Information Storage and Retrieval Systems for Individual Researchers, rev. of, 415-16

James, Thomas, 43-49; correction, 289

Jennings, John M., The $L$. of the Coll, of William and Mary in Virginia, 1693-1793, rev. of, 58-59

Jordan, Rohert Thayer, Tomorrow's L.: Direct Access and Delivery, rev. of $356-57$

Josey, E. J., "Community use of jr, coll. Is,-a symposium" [results of a survey of jr. coll. ls. in Mar. 1968] 185-98

\section{$\mathrm{K}$}

Kaplan, Louis, "Information retrieval from the management point of view," 169-73

Kaser, David, "Modernizing the univ. 1. structure," 227-31; Book Pirating in Taiwan, rev. of, 58 ; rev, 353

Kenney, Brigitte L., rev., 280-81

Kilgour, Frederick G., rev., 204

Krzys, Richard, A History of Education for Lnship in Colombia, rev. of, 419-21

Kujoth, Jean Spealman, Ls, Readers, and Book Selection, rev. of, $359-60$

\section{L}

Leonard, Lawrence E., Centralized Book Processing: a Feasibility Study Based on Colorado Academic Ls., rev. of, 119-21

Lewis, Alfred J., "The use of an automatic answering service in research ls.," 107-08

Lewis, Ralph W., "User's reaction to microfiche; a preliminary study," 260-68

Lewis, Stanley, L. Science, rev. of, 355

Libraries and Cultural Change, Benge, rev of 357-58

Libraries, Readers, and Book Selection, Kujoth, rev. of, 359-60 The library as a social agency response to social change," Pings, 174-84

Library Automation; a State of the Att ... Salmon, rev, of, 204

The Library of the Coll. of William and Mary in Virginia, 1693-1793, Jennings, rev. of, $58-59$

Library Response to Urban Change: a Study of the Chicago Public L., Martin, rev. of, 203-04 


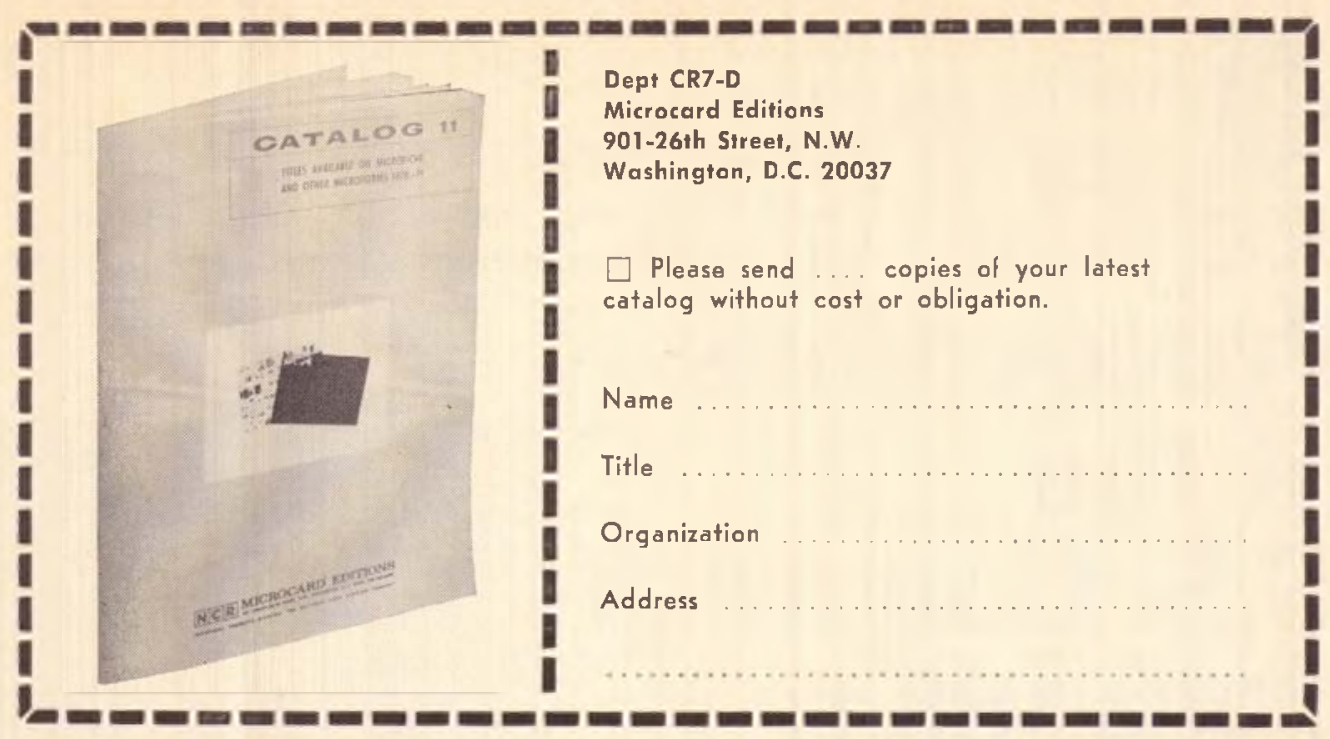

\section{IMPORTANT TITLES ON MICROFICHE}

BOOKS FOR COLLEGE LIBRARIES (BCL-4). Selected titles from the chapter "History-United States

THE BRITISH THEATRE. London, 1908. 25 vols. [BCL, p. 639]

Chalmers, A. THE WORKS OF THE ENGLISH POETS. London, 1810. 21 vols. [BCL, P. 636]

Fielding, H. COMPLETE WORKS. N.Y., Croscup \& Sterling, 1902.16 vols. $[B C L$, p. 656]

James, H. THE NOVELS AND TALES OF HENRY JAMES. N.Y., 1907-17. 26 vols. [BCL, P. 729]

Morris, W. COLLECTED WORKS. N.Y., 1910-15. 24 vols. [BCL, p. 677] . \$55.00 SOUTHERN WORKMAN. Vols. I-68 (1872-1937) (35mm microfilm) ....... \$150.00 


\section{THE UNITED STATES}

\section{HISTORICAL DOCUMENTS INSTITUTE}

announces the first in a new series of dual media reference collections for the expanding academic library

\section{Proceedings of the \\ U.S. Congress 1789-1964}

"... an essential resource for all courses relating to American Goverument... should be availalle in every academic libraxy."

-Evan Farber, author of Periodicals for the College Library (Faxon, 1957 \& 1970)

... including: the Annals of Congress (17891824), the Register of Debates (1824-1837), the Congressional Globe (1833-1873), and the Congressional Record (1873-1964).

Together, they present the only official narrative of the first 175 years in the history of the Legislative Branch of the U.S. Government.

available for the first time in one convenient DUAL-MEDIA reference set

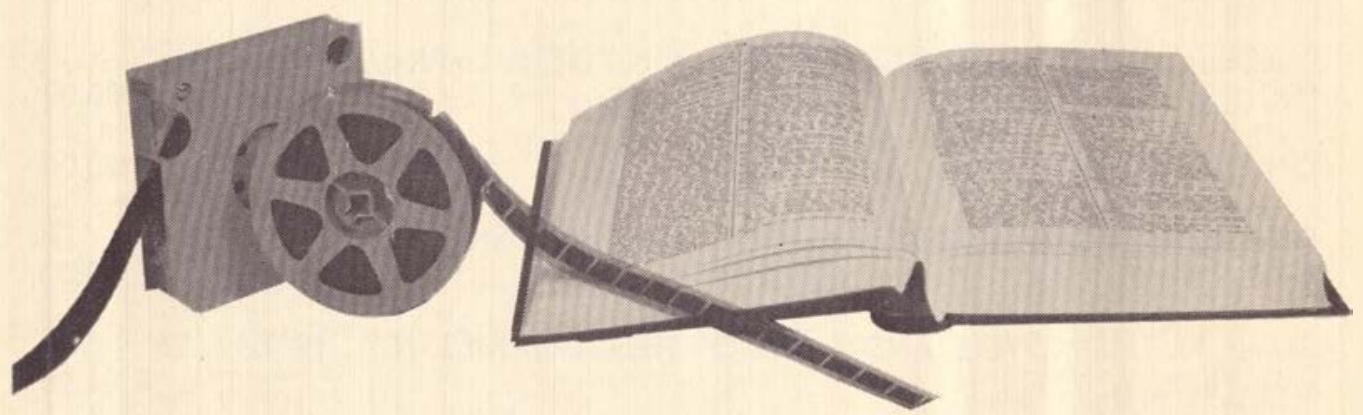

477 reels of $35 \mathrm{~mm}$ microfilm containing the complete text of speeches, debates, votes, trials, Presidential messages, and all Appendices.
101 casebound full-size reprint volumes containing Indexes to all 220 regular and special sessions, Indexes to the Appendices, and the Histories of Bills and Resolutions.

Now you can buy this complete set of both microfilm and index volumes for just slightly more than one major micropublisher charges for the microfilm runs alone.

To: The United States Historical Documents Institute Inc.

1647 Wisconsin Avenue, N.W., Washington, D. C. 20007, (202) 965-2121

Send for our free catalog listing single index volumes and microfilm reels

Name

Address

City State Zip

DEDUCT 5\% FROM ALL PRICES IF PAXMENT IS ENCLOSED WITH ORDER 


\section{The Dual-Media Concept}

\section{... saves money and space without sacrificing research effectiveness}

As viewed by Evan Farber, author of Classified List of Periodicals for the College Library (Faxon, 1957 \& 1970) and a member of the Institute's Editorial Advisory Board,

"Because The Congressional Record and its predecessors contain so much information about the activities of Congress, including the votes and near-verbatim reporting of debates, it is an essential resource for all courses relating to American government and should, therefore, be available in every academic library. On the other hand, its very comprehensiveness not only creates a space problem for most libraries, but also results in disproportionately high acquisitions costs for new libraries attempting to acquire complete backfile runs.

Microfilm offers a partial solution in that it is less expensive initially and saves valuable shelf space. One of the major obstacles to its acceptance however, has been the fact that students and other researchers find that searching for references in microform indexes is inconvenient, time consuming, and ultimately discouraging to effective research.

"Having the Proceedings of Congress available then, in the Dual-Media Edition, with the proceedings and appendices on microfilm and the Sessional Indexes and Histories of Bills and Resolutions in printed form (the Record is almost useless without its Indexes], means that libraries can now offer the wealth of this resource plus the convenience of the Indexes in book format, yet use a minimum of space and money."

\section{THE UNITED STATES HISTORICAL DOCUMENTS INSTITUTE}

has been founded in Washington, D.C. to republish complete collections of basic out-of-print historical reference materials in "Dual-Media Editions." Initially, special emphasis will be placed on those basic serials which have been recommended for new or expanding academic libraries which are building collections in the fields of U.S. History and Government. These "Dual-Media Editions" will be reproduced in optimum combinations of microfilm and book formats to provide maximum gains in serials reference capacity at minimum cost.

\section{EDITORIAL ADVISORY BOARD}

This distinguished and representative Editorial Advisory Board has been organized to assist the Institute in its planning and program evaluation activities.

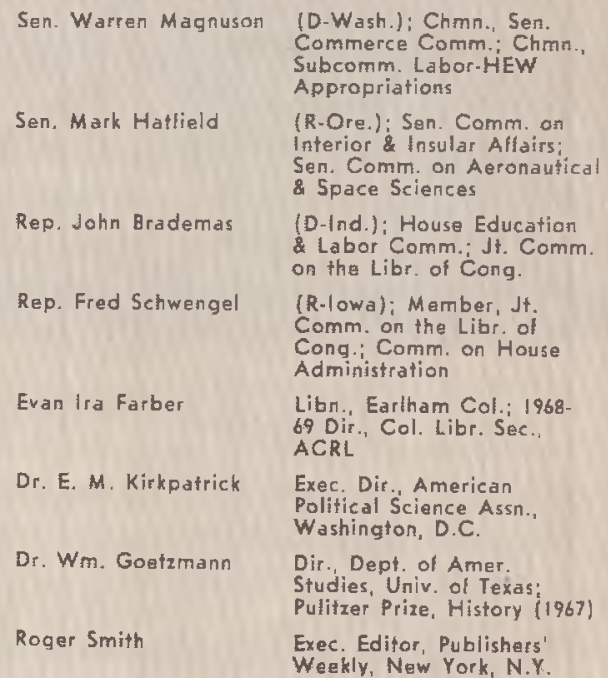

Roger Smith

Weekly, New York, N.Y

Dual-media sets for each Congress and Session are also available, as are single microfilm reels and index yolumes. Send for our detailed catalog listing individual units. All items are sold "on approval" and may be returned for credit within sixty days after delivery.

USE THIS CONVENIENT PRICE SCHEDULE AS YOUR ORDER FORM FOR DUAL-MEDIA SETS.

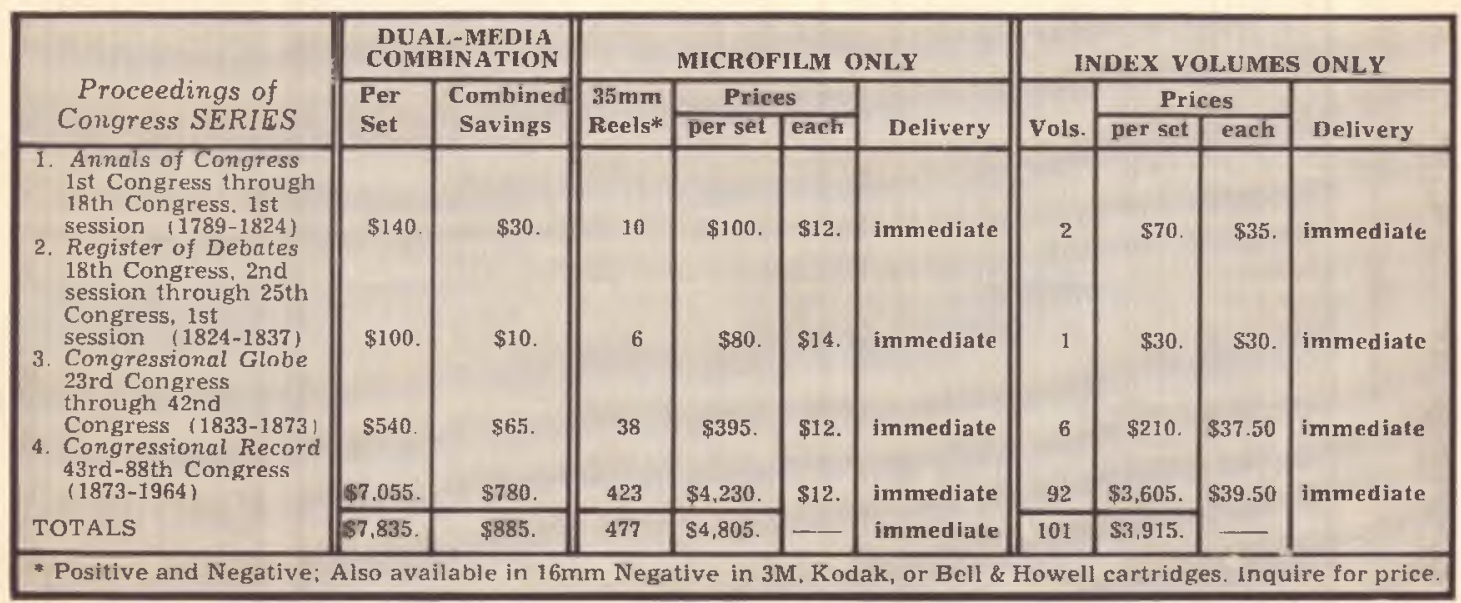




\title{
вооке \\ for Junior dollege Iibreries
}

James W. Pirie, Compiler-Editor

\section{An authoritative list of approximately 20,000 recommended books}

\author{
for use in junior and community college \\ libraries - four-year college libraries • high \\ school libraries • public libraries
}

Here is a reference work of monumental importance to the library world. For yuidance in selecting titles for a new library, for providing fill-ins in a sparse collection, for updating an old established collection -Books for Junior College Iibraries is the best answer.

'This definitive list is a scholarly distillation of recognized superior college library collections, outstanding bibliographies, the best thinking of hundreds of expert consultants, and skilled editing.

From Anatomy to Zoology, subject coverage is extensive (sec listing at right). Each entry includes author and titlc, subtitle, edition, publisher, date of publication, price in the country of publication, pagination, Library of ('ongress card number. Order your copy now.

\$35.00

The publication of Books for Junior College Libraries is endorsed by the Joint Committee on Junior Colleges of the American Association of Junior Colleges and the American Library Association; and the Funior College Section of the 1 ssociation of College and Research Libraries, a division of the 1 L.A.
SUBJECTS COVERED IN

BOOKS FOR JUNIOR COLLEGE LIBRARIES

- Philosophy

- Religion

- Psychology

- Geography

- Social Science and Sociology

- Anthropology

- Political Science

- Law

- Human Anatomy and Physiology

- Education

- Music

- Art

- Language

- Recreation, Sports

- Mathematics

- Physics

- Chemistry

- Geology

- Astronomy

- Biology

- Medicine

- Technology and Engineering

- Drama, Theater. and Dance

- General Science

- Zoology
- Literature

General

American

English

French

German

Spanish, Latin-American and Portuguese

Other European

Oriental and African

- History

General

Europe

Africa

Asia

Australia,

Oceania, Polar Regions North America

Latin America

- Economics and Business

- Military and Naval Science

- Botany and Agriculture

- General Works

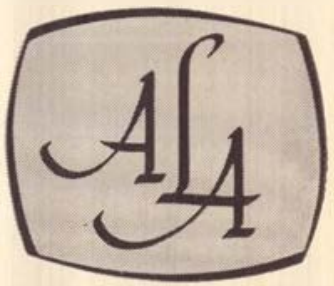


"Library roles in American higher education," Wilson, 96-102 Library Science, Farley and Lewis, rev, of, 355

A List of the Original Appearances of Dashiell Hammett's Magazine Work, Mundell, rev of, 280

Litton, Gaston, A History of Education for Lnship in Colombia, rev, of, 419-21

M

McNiff, Philip J., rev., 58

Magazines for Millions: the Story of Specialized Publications, Ford, rev. of, 283-84

Magnetic tape cassettes, $\mathbf{s 2 7}$

Maier, Joan M., Centralized Book Processing: a Feasibility Study Based on Colorado Academic Ls., rev. of, 119-21

"Major decision points in 1. automation,"Veaner, 299-312

Malinowsky, H. Robert, rev. 422

The Manual of Psychiatric Tele vision; Theory, Practice, Imagination, Onder, rev, of, 280 81

Martin, Lowell A., L. Response to Urban Change: a Study of the Chicago Public L., rev. of 203-04

Massman, Virgil F., "A minimum budget for current acquisitions," 83-88

Mexico's L and Information Services: a Study of Present Conditions and Needs, White, rev of, 353

Mihailovich, Vasa D., rev., 418 19

"A minimum budget for current acquisitions." Massman and Patterson, 83-88

"Modernizing the univ. 1. structure," Kaser, 227-3I

Moriarty, John H., "Academic in deed," 14-17; "The types and needs of academic 1 . users: a case study of 6,568 responses," 403-09

Morrison, Perry D., rev., 419-21

Mundell, E. H., A List of the Original Appearances of $\mathrm{Da}$ shiell Hammett's Magazine Work, rev, of, 280

\section{$\mathrm{N}$}

National Academy of SciencesNational Academy of Engineering, Scientific and Technical Communication: a Pressing National Problem and Recommendations for Its Solution. rev. of, 121

National Book Awards, judges chosen, s65-66

Neal, K. W., British Univ. Ls., rev. of, 42i-22

Necrology, s19; s89; s125; s166; s199; s230-31; s261; s312 Nelson Jerold rev, 359-60

Netherlands. Rijkscommissie van advies inzake het bibliotheekswezen, $D e$ wetenschappelije bibliothekin in Nederland; programma voor een beleid op lange termijn, rev. of 121-22

New Zealand. Working Party on Education for Lnship, Education for Lnship: Report of the Working Party, rev. of, 41617

News from the field," s5-16, s28-55; s73-84; s97-122. s145-62; s178-96; s212-28; s241-59; s275-87; s297-308; s328-46

"News from the Sections," s16265; s 196; s259-60; s309-10

Onder, James J., The Manual of Psychiatric Television; Theory, Practice, Imagination, rev. of. 280-8I

$\mathbf{P}$

Painter, Ann F., rev., 121

Patterson, Kelly, "A minimum budget from current acquisitions," 83-88

Perreault, J. M., rev., 205-06

Personnel, s17-19; s56-57; s8889; s122-25; s165-66; s199200 ; s229-31; s260-61; s28790 ; s310-12; s347-50

Pettit, Henry, rev., 358-59

"The Ph.D. in L. Science," Richmond, 313-17

Physical Sciences, Royal Institution $L$. of Science, Bragg and Porter, eds., rev. of, 422

Pings, Vern M., "The 1, as a social agency, response to social change," 174-84

Pirie, James W., comp., Books for Jr. Coll. Ls.; a Selected List of Approximately 19,700 Titles rev of 355-56

Porter, George, ed., Physical Sciences, Royal Institution L. of Science, rev, of, 422

Poulos, Angela, rev, 414-15

Princeton Univ Annex I. 16068

"Problems in the life of a univ. In: Thomas James, 1600 1620," Davis, 43-49; correction, 289

Prolegomena to L. Classification, $3 \mathrm{~d}$ ed., Ranganathan, rev. of, 205-06

"Quantitative management in ls.," Heinritz, 232-38

\section{$\mathrm{R}$}

Randall, David A., rev., 282-83

Ranganathan, S. R. Prolegomeno to L. Classification, $3 \mathrm{~d}$ ed., rev. of, 205-06

Reader in Research Methods for Lnship, Bundy and Wasserman, eds., rev. of, 419

Ready, William, "Bibliocentre: an essay in central processing at coll. level," 50-54

"Reference books," Sheehy, 109 $17 ; 269-79$

Resnikoff, H. I., Computerized L. Cats.: Their Grouth, Cost, and Utility, rev. of, 123

Retirements, s19; s89; s166; s199-200; s231; s261; s290; s312: s

Richmond, Phyllis A. "The Ph.D. in L. Science," 313-17

Rouse, Roscoe, "Automation stops here: a case for manmade book collections," 147 54

Royal Institution L. of Science Physical Sciences, ed. by William Lawrence Bragg and George Porter, rev. of, 422
Rzasa, Philip V., "The types and needs of academic 1. users: a case studv of 6,568 responses," 403-09

Salmon, Stephen R., ed., L. $A u$ tomation: a State of the Att rev, of, 204

Sandoe, James, rev, 280

Schad, Jasper G., "Allocating book funds: control or planning?" 155-59

Scientific and Technical Communication: a Pressing $\mathrm{Na}$ tional Problem and Recommendations for Its Solution, National Academy of SciencesNational Academy of Engineering, rev. of, 121

"The separately housed undergraduate 1. versus the univ. 1.," Burke, 399-402

Shaw, Ralph R., "Catcall," 8995

Sheehy, Eugene $P_{\text {, " }}$ "Selected ref. books." 109-17;'269-79

Smith, Eldred, "Academic status for coll. and univ. Ins.-problems and prospects," 7-13

Southeastern Europe: a Guide to Basic Publications, Horecky, rev of 418-19

"Standards for univ. Is.," Downs and Heussman, 28-35

Stockham, Kenneth Alan, The Government and Control of $I s_{\text {., }}$ rev. of, 122-23

Stokes, Katharine M., "From inside the DLP," s25-26; s6970 ; s95-96; s141; s176-78; s211; s240; s272; s327-28

Storage ls., 160-68

"Student employees in academic ls.," Cottam, 246-48

Stursa, Mary Lou, "Academic I. procedures for providing students with required reading materials," 103-06

Suppressed Commentaries on the Wiseian Forgeries. Addondum to an Enquiry, Todd, rev, of, $282-83$

$\mathrm{T}$

Teach-in: the academic In.'s key to status?" Cassata, 22-27

Thompson, James, An Introduction to Univ. L. Administration, rev. of, 421-22

Todd, William B., Suppressed Commentaries on the Wiseian Forgeries. Addendum to an Enquiry, rev of, 282-83

Tolkien Criticism. An Annotated Checklist, West, rev. of, 422 23

Tomorrow's L.: Direct Access and Delivery, Jordan, rev. of, 356-57

Trueswell. Richard W. "Article use and its relationship to individual user satisfaction," 239-45

The types and needs of academic 1 users: a case study of 6.568 responses, "Rzasa and Moriarty, 403-09

The Undergraduate L., Braden, rev. of, 417-18

"The use of an automatic answering service in research Is.," Lewis, 107-08 
"User's reaction to microfiche; a preliminary study," Lewis, 260-68

V

Veaner, Allen B., "The application of computers to 1 . technical processing," 36-42; "Major decision points in 1. automation," 299-312

Vesenyi, Paul E., European Periodical Literature in the $\mathrm{SO}$ cial Sciences and the Humanities, rev. of, 414-15

\section{W}

Ward, Dederick C., rev., 422 23

Wasserman, Paul, ed., Reader in Research Methods for Lnship, rev. of, 419

West, Richard C., Tolkien Criticism. An Annotated Checklist, rev. of, 422-23

De wetenschappelijke bibliotheken in Nederland; programma voor een beleid op lange termiin, Netherlands. Riikscommissie van advies inzake het bibliotheekswezen, rev, of 121-22
White, Carl M., Mexico's L. and Information Services: a study of Present Conditions and Needs, rev. of, 353

Wilson, Logan, "L. roles in American higher education," 96-102

Wolf, Edwin, 2d, rev., 58-59

Wright, James, "Fringe benefits for academic 1. personnel," $18-21$

\section{Y}

Young, Arthur P., rev., 353-55 


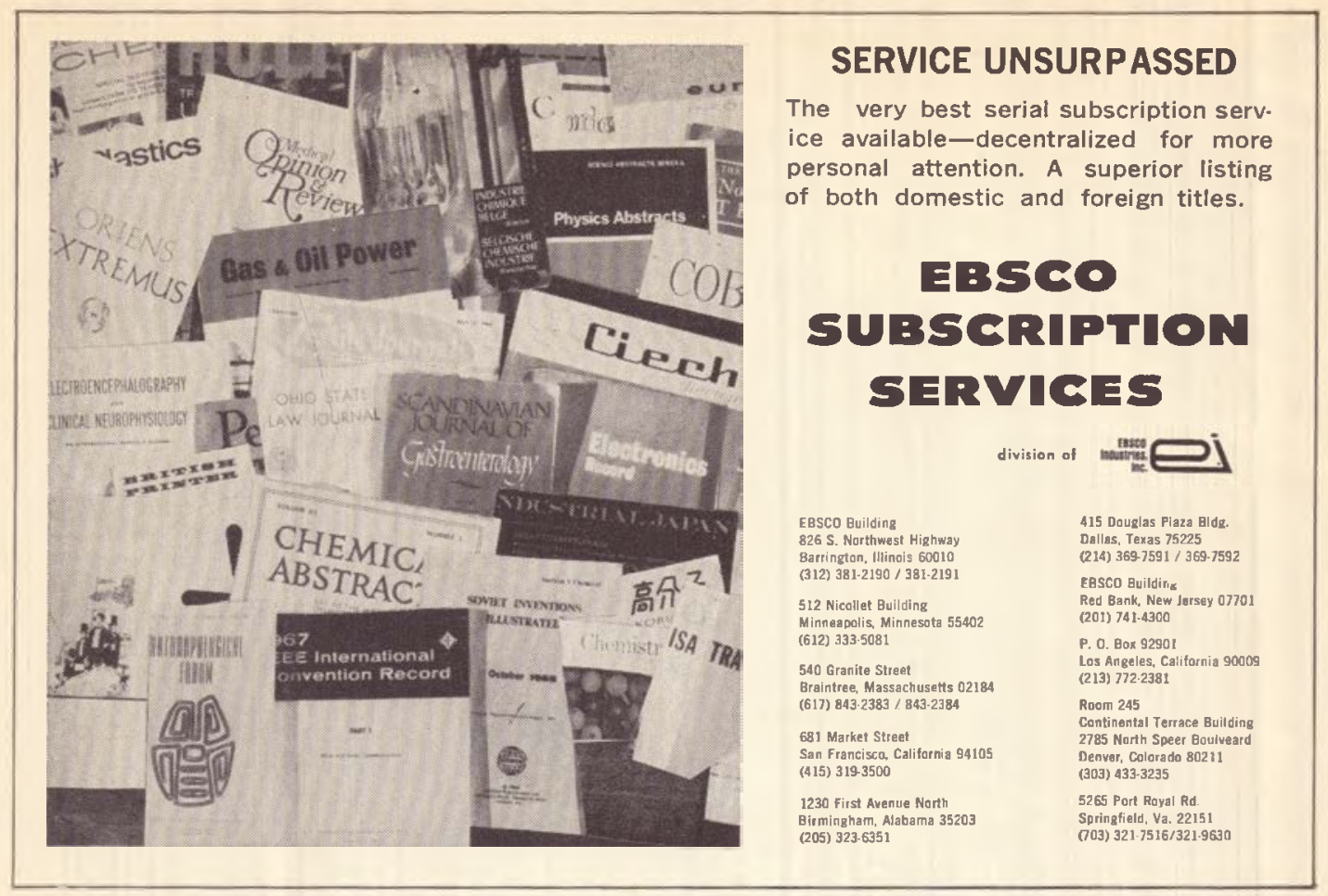

\section{complete book}

\section{Services for academic libraries}

For information about Baker \& Taylor's

University \& College Library New-Book Service

(a standing order plan)

BATAB (Baker \& Taylor's Automated Buying System)

or Current Books for Academic Libraries (a publication)

-write to the Baker \& Taylor division nearest you.

EASTERN DIVISION, Somerville, N. J. 08876

MIDWEST \& SOUTHERN DIVISION, Momence, III. 60954

WESTERN DIVISION, Reno, Nev. 89502

\section{The Baker \& Taylor Co.} AMERICA'S LEADING BOOK WHOLESALER 


\section{The Microbook Library}

of American Civilization includes

15 sets of catalogs for maximum

use by faculty and students.

\section{They'll have author, title, and subject catalogs plus the Biblioguide for all 20,000 volumes.}

This library is ready to be used the very day you receive it. That's why updated Library of Congress cataloging for author, title, and subject is part of the package. In addition, you get a three volume, 2,000 page Biblioguide, or topical index.

The Biblioguide is an important addition to the standard bibliographic support. It provides some 500 themes of special interest to students of American civilization. Each theme is introduced by a research guide describing the range of materials to be found under the theme in the library and followed by an average of 250 bibliographic citations. This makes a total of approximately 125,000 references on all subjects to help both student and scholar reach deep within the contents of the library.

The Library of American Civilization is offered to you in Microbook form, a book-range microfiche system that puts up to 1,000 pages on a single fiche, or card. For storage, retrieval, check-out and reading convenience, there will be one book per fiche for most single volume works. High resolution readers, including a lap reader, deliver high quality Microbook images, for comfortable extended reading without eye strain.

This 20,000 volume library costs less than
$\$ 1.00$ per volume and takes only card file space. It's the first in a series of Britannica Microbook Libraries.

The Library of American Civilization includes five sets of bound catalogs and Biblioguides and ten sets in Microbook form. Some colleges plan to supply personal catalogs and Biblioguides to key faculty members as an important aid in course preparation and to increase library usage. Standard catalog cards are optional.

For complete information, send in the coupon below. We'd like to send you our new 20 page booklet, "The Microbook Library Series," and tell you about our pre-publication price.

Delivery time is near.

\section{To: Library Resources, Inc., Dept. M}

201 E. Ohio Street

Chicago, Illinois 60611

Please send your new "Microbook Library Series" booklet.

Name

Title

School or Library

Address

City State Zip

\section{LibraryResources,Inc.}


Sept, 30-Oct, 2, 1971: The Indiana Library Association will meet at Stouffer's Inn, Indianapolis, Indiana. Further information can be obtained from Jane G. Flener, President, Indiana Library Association, Indiana University Library, Bloomington, Indiana 47401.

\section{IS CELLANY}

- Eastern Michigan Untversity, Ypsilanti, and Hampshure College, Amherst, Massachusetts, will each receive a grant of $\$ 50,000$ for innovative library-centered programs under a matching fund program of the Council on Library Resources and the National Endowment for the Humanities. The grants for the fiveyear programs, to which the National Endowment for the Humanities and the Council contribute equally, are being matched in like amounts by the two institutions.

Hampshire College, of which Dr. Franklin Patterson is president, opened this fall as an experimental, independent liberal arts institution. Several interrelated activities are planned in connection with the Hampshire program. These include: investigations of what users do and do not do in libraries; a multimedia orientation program intended to instruct users in self-help; and the training of student reference assistants for service in the library and outside of it. Incident to the project will be the development of a range of video tape, film slides, and limited computer programs in support of a wide variety of user needs and which may also be useful to other libraries. Among other features of the project will be clearinghouse service for information on similar efforts and the possibility of serving as a model for other libraries contemplating such projects.

Eastern Michigan, with a student body expected to exceed 20,000 during the 1970-71 academic year, in its "Library Outreach" program is seeking to identify for the teaching faculty the contributions librarians are prepared to make to the students' learning, to encourage their working together to achieve this goal, and to demonstrate the role librarians can play in the motivation of students. A new position, "Orientation Librarian," is being created and two persons assigned full-time to this work. They will meet with classes and with small groups, hold follow-up sessions, meet the library demands resulting from previously determined student work assignments, endeavor to provide a more personalized approach to specific bibliographic resources, and work toward a closer library-faculty-student relationship. Among other features of "Project Outreach" will be studies of the patterns of library use and comparisons of student groups within and without the program. As at Hampshire, selected students will be trained in the use of basic resources to assist other students at times when professional help is not available.

- Vice Admiral Edwin B. Hooper, USN (Ret.), Director of Naval History, recently announced that all components of the Naval History Division are now located in the Washington Navy Yard, 9th and M Streets, S.E., Washington, D.C. 20390. Previously, most of the Division's offices were in Northwest Washington, at the Main Navy Building.

Of particular interest to scholars is the Navy Department Library, administered by the $\mathrm{Na}$ val History Division, which is now in Building 220 of the Washington Navy Yard. This library of approximately 120,000 volumes is an outstanding resource for students of U.S. Naval History and of numerous fields related to the Navy. In addition to published official and unofficial works and extensive holdings of bound serials, the Library has a number of special collections. These include rare books, cartographic materials, manuscript histories, and extensive microfilm holdings. The latter category includes many of the major series of official naval records in the U.S. National Archives. Microfilms and most published works can be made available to scholars through interlibrary loan. A summary of the Library's holdings is now at the press and will be provided to interested scholars upon request.

The Naval History Division's Operational Archives, housed in Building 210, Washington Navy Yard, has extensive collections relating to naval operations, strategy, and policy, primarily dating from 1940 to the present. In addition to official records from naval fleet commands and the Navy Department, the Archives has personal papers of some recent naval leaders and extensive microfilmed holdings of German and Japanese naval archives. Most of the Operational Archives' holdings dating prior to 1953 may be made available to scholars. Detailed information on the resources of the Operational Archives, as well as other repositories in the Washington area, will appear in a revised and enlarged edition of U.S. Naval History Sources in the Washington Area and Suggested Research Subjects, which is scheduled for publication late in 1970. Copies of this publication will be provided to scholars upon request.

- The New York Public Library's PEACE --JUSTICE-PROGRESS Exhibition, celebrating the 25th Anniversary of the United $\mathrm{Na}$ tions, is on view in the Central Building of the New York Public Library at Fifth Avenue and 42nd Street. Among the highlights are a handwritten first draft of the Declaration of Human Rights by Rene Cassin of the Provisional French Government, and a typed report on the Commission on Human Rights signed by its chairman, Eleanor Roosevelt. 
The exhibition salutes more than twenty years' cooperation between the New York Public Library and the United Nations, whose delegates and staff have the unique privilege of borrowing documents and books from the Research Libraries. This courtesy was extended to the international body in its early years in order to provide it with those essential materials that its own small library at Lake Success did not contain. The present U.N. Library is impressive but specialized, and through its U.N. liaison officer, Dr. Clementine Zernik, the New Iork Public Library continues to supplement the U.N. collections.

Also included in the exhibition, from the Library's Manuscript Division, are the papers of Sol Bloom, U.S. Representative at the San Francisco Conference and signer of the U.N. Charter for the United States. Significant among these is a copy of the report to the President on the San Francisco Conference containing handwritten messages of thanks to Bloom from Harry Truman, Cordell Hull, Harold Stassen, and Edward R. Stettinius, Jr., among others. Bloom's personal photographic record of the signing of the Charter and events relating to the conference are also on display.

- The University of California libraries have been involved with automation for over five years. Every campus of the University utilizes electronic data processing in some way in its daily operations. Particularly noteworthy are the serials control systems in operation at UCSD and UCD, the book catalog used at UCSC, the circulation system at UCLA, and the subject authority control systems in use at UCSD and UCSB. These pioneering efforts have provided the experience which has now resulted in a new University-wide program aimed at the development of common systems for the UC Libraries which are both more effective and less costly.

The UC LSD Program is the outgrowth of many years of work undertaken by the UC Institute of Library Research under the directorship of Dr. Robert Hayes. The establishment of an operations task force, for library automation, under ILR sponsorship, was promoted and guided by Ralph Shoffner. Other major projects of the ILR include the development of a union catalog supplement; listing library materials acquired by the UC libraries between 1962 and 1967, based on a file of machine-readable records in a MARC format; and the development of a center for information services under an NSF grant which will make available to library patrons throughout the University information contained in a large library of machine-readable data bases.

The new University-wide office responsible for directing the University of California systems development work (including automa- tion) has been established at the Santa Barbara campus. Fred Bellomy, recently appointed manager of the University of California Library Systems Development (UC LSD) Program. was formerly head of the library systems staff at the University library on the Santa Barbara campus. The first year's $\$ 300,000$ Feasibility Phase has been funded jointly by the Office of the University President and the University libraries. Total development costs for the entire program are projected at more than $\$ 15$ million and the development is expected to span seven years or more. The objectives of the first year Feasibility Phase includes the establishment, at a high level of confidence, of the potential for significant long-term fiscal advantages to both the state of California and the University.

\section{P U B L I C A T I O N S}

- The U.S. National Section of the Pan American Institute of Geography and History has inaugurated a new series of occasional publications on Latin American geography, history, and cartography. The series is designed to stimulate research and writing on Latin America, to provide a forum for the dissemination and coordination of information, and to keep Latin Americanists abreast of current research priorities and goals. The series will consist of bibliographies, pamphlets, and monographs. The first publication, A Bibliography of Latin American Coastal Geomorphology, written by Norbert P. Psuty of Rutgers University, was issued in September. This bibliography should provide an important guide to current research frontiers and problems in Latin American coastal geomorphology. The bibliography includes references from the early twentieth century, although most date from the middle fifties. The bibliography costs $\$ .75$. Individuals interested in receiving this publication or announcements of future publications should contact Dr. Arthur L. Burt, Chairman, U.S. National Section, PAIGH, Department of State (Room 8847), Washington, D.C. 20520.

- The Committee on Gerontology, Western Michigan University, announces publication of a recently compiled bibliography, Gerontology; an Annotated Bibliography of Selected Publications Available in the Dwight Waldo Library. The bibliography lists guides, handbooks, dictionaries, encyclopedias, bibliographies, periodicals, indexes, abstracts, dissertations, statistical sources, directories, and state and federal documents as sources for the study of gerontology. In addition, the Appendix lists practical information about organizations working with the 
aged. Althongh this bibliography is geared primarily to help students and researchers on our campus, it would also be valuable to persons anywhere who are interested in the problems of old age, since many of the materials listed can be found in most libraries. The bibliography consists of 47 pages compiled by Dr. Louis Kiraldi, Documents Librarian, and is available for $\$ 2.00$ from the Division of Continuing Education, Western Michigan University, Kalamazoo, Michigan 49001.

- The August 1970 issue of the list of Graduate Library School Programs Accredited by the American Library Association is available upon request from the Office for Library Education, American Library Association, 50 East Huron Strect, Chicago, Illinois 60611. Issued semiannually by the Association's Committee on Accreditation, the official list gives the name and address of each library school offering an accredited program, the name of the dean or director, and the name of the degree to which the accredited program leads. Other information includes the number of hours of work required for the degree, the undergraduate prerequisites if any, and the cost of tuition. Library schools offering doctoral and post-Master's specialist or certificate programs are so designated on the list.

- In response to the need for billiographical control of U.S. Government publications printed outside the U.S. Government Printing Office, the Library of Congress has recently issued Non-GPO Imprints Received in the Library of Congress, July 1967 through December 1969: A Selective Checklist. Prepared by the Federal Documents Section of the Library's Exchange and Gift Division, the Checklist is limited to those non-GPO imprints deemed to be of some research or informational value and which fall outside the scope of the Monthly Catalog of United States Government Publications, as well as the other main bibliographies of United States Government-sponsored publications. The Checklist is divided into two sections. The first contains 1,112 monographs and monographs in series. These entries are arranged alphabetically by corporate heading and numbered so that they may be approached through the subject index. The section lists periodicals, also arranged alphabetically by corporate heading, but unnumbered since no subject headings have been assigned to them. This publication is avalable postpaid trom the Card Division, Li. brary of Congress, Building 159, Navy Yard Annex, Washington, D.C. 20541 for \$1.25.

- A Research Design for Library Cooperative Planning and Action in the Washington,
D.C. Metropolitan Area, prepared by Booz, Allen and Hamilton, Management Consultants, is available in limited quantities from the Biological Sciences Communication Project of the George Washington University Medical Center, 2001 S Street, N.W., WVashington, D.C. 20009. Contact the Center regarding price.

- The Ceorge Peabody Library School has published Toward an Environmental Source Book, a collection of reviews, bibliographies, and proposals prepared by a class in the School of Library Science. This 55-page publication on a topic of vital interest contains a great deal of information on the literature related to the environment, inclucling detailed bibliographies of books, periodicals, and films. A scetion on "Voices for the W'ilderness" describes some organizations dedicated to conservation of our resources, and "Problems and Proposals" suggests courses of action to follow Farth Day. This publication is available for $\$ 1$ (prepaid, check or money order) from the School of Library Science, George Peabody College for Teachers, Nashville, Tennessee 37203

- The School of Library and Information Services of the University of Maryland has announced the publication of The Universal Decimal Classification, a programmed instruction course by Hans Wellisch. With the aid of this book, students can become familiar with the principles and techniques of UDC in a classroom situation; it may be used as a manual for self-instruction by those who look to the UDC as a suitable system for the organization of information. The Universal Decimal Classification by Hans Wellisch-School of Library and Information Services, University of Maryland, 1970 , SBN 911 808-04-4-is distributed by the Student Supply Store (University of Maryland, College Park, Maryland 20742) at $\$ 3.50$ a copy.

- The Yale University Library Development Department has made available for general distribution a new document relating to the Yale Bibliographic, which is now completing its third year of use at the Yale Medical Library. The Yale Bibliographic System User's Handbook (Iocument D-12) is a loose-leaf document, comprising about 92 pages, which contains sections on cataloger's instructions, keypuncheres instructions, prootreader's instructions, error and operational messapes, control cards, etc. The Manual sells for $\$ 3.50$. Checks should be made payable to the Yale University Library. Also available is the Yale Bibliographic System Time and Cost Analysis which sells for $\$ 1.12$. 